TẠP CHÍ KHOA HỌC ĐẠI HỌC TÂN TRÀO

ISSN: $2354-1431$

http://tckh.daihoctantrao.edu.vn/

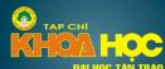

THE UNIVERSALIZING PRESCHOOL EDUCATION FOR 5-YEAR-OLD CHILDREN IN THAI NGUYEN PROVINCE (2010-2020)

Nguyen Thi Que Loan ${ }^{1, *}$, Hoang Thi Tu ${ }^{l}$

${ }^{I}$ Thai Nguyen University of Education, Vietnam

*Email address: loanntq@tnue.edu.vn

http://doi.org/10.51453/2354-1431/2021/623

\section{Article info}

Recieved: 03/8/2021

Accepted: 05/9/2021

\section{Keywords:}

preschool education universalization, 5-year-old children, policies, Thai

Nguyen province

\begin{abstract}
Preschool education is the first level in the national education system in Vietnam. The knowledge and skills of children formed at this level that contributed to building a child's personality and character. Recognizing the importance of preschool education, the Party and State of Vietnam have issued many policies, including the policy of universalizing preschool education for 5year-old children. By method of quantitative and qualitative research, the article presents the implementation solutions and results achieved in the work of universalizing preschool education for 5-year-old children in Thai Nguyen province. From there, recommendations are made to firmly consolidate the results of preschool education universalization.
\end{abstract}


TẠP CHÍ KHOA HỌC ĐẠI HỌC TÂN TRÀO

ISSN: $2354-1431$

http://tckh.daihoctantrao.edu.vn/

\title{
PHỔ CẬP GIÁO DỤC MẦM NON CHO TRẺ 5 TUỔI Ở TỈNH THÁI NGUYÊN (2010- 2020)
}

\author{
Nguyễn Thị Quế Loan ${ }^{l, *}$, HoàngThị Tü ${ }^{l}$ \\ ${ }^{I}$ Truò̀ng Đại học Su phạm Thái Nguyên, Việt Nam \\ *Địa chi email: loanntq@tnue.edu.vn
}

http://doi.org/10.51453/2354-1431/2021/623

\section{Thông tin bài viết}

Ngày nhận bài: 03/8/2021

Ngày duyệt đăng:05/9/2021

\section{Tù̀ khóa:}

Phổ cập giáo dục, mầm non, trẻ 5 tuổi, chính sách, tỉnh Thái Nguyên

\section{Tóm tắt}

Giáo dục mầm non là cấp học tiền học đường trong hệ thống giáo dục quốc dân ở Việt Nam. Những kiến thức, kĩ năng của trẻ được hình thành ở cấp học này góp phần xây dựng con người và tính cách của trẻ. Nhận thức được tầm quan trọng của giáo dục mầm non, Đảng và Nhà nước Việt Nam đã ban hành nhiều chính sách, trong đó có chính sách phổ cập giáo dục mầm non cho trẻ 5 tuổi. Bằng phương pháp nghiên cứu định lượng và định tính, bài viết trình bày những giải pháp thực hiện và kết quả đã đạt được trong công tác phổ cập giáo dục mầm non cho trẻ 5 tuổi ở tỉnh Thái Nguyên. Từ đó, đưa ra những khuyến nghị nhằm củng cố vững chắc kết quả phổ cập giáo dục cấp học mầm non.

\section{1. Đặt vấn đề}

Phổ cập giáo dục là quá trình tổ chức để mọi công dân đều được học tập và đạt tới một trình độ học vấn tối thiểu theo quy định của Nhà nước (Chính phủ, 2011). Là cấp học tiền học đường trong hệ thống giáo dục quốc dân ở Việt $\mathrm{Nam}^{1}$, Giáo dục mầm non thực hiện việc nuôi dưỡng, chăm sóc, giáo dục trẻ em từ 03 tháng tuổi đến 06 tuổi. Những kiến thức, kĩ năng trẻ em được học ở cấp học mầm non sẽ góp phần xây dựng con người và tính cách của trẻ sau này. Nhận thức được tầm quan trọng của giáo dục mầm non, năm 2009, vấn đề phổ cập giáo dục mầm non cho trẻ em 5 tuổi được Quốc hội nước Cộng hòa xã hội chủ nghĩa Việt Nam đưa vào

\footnotetext{
${ }^{1}$ Hệ thống giáo dục quốc dân ở Việt Nam bao gồm 4 cấp học: giáo dục mầm non, giáo dục phổ thông, giáo dục nghề nghiệp và giáo dục đại học.
}

Luật Giáo dục (Quốc hội, 2009) đánh dấu sự phát triển của giáo dục mầm non. Tiếp đó, ngày 09/02/2010, Thủ tướng Chính phủ ra Quyết định số 239/QĐ-TTg về việc phê duyệt Đề án phổ cập giáo dục mầm non cho trẻ em 5 tuổi giai đoạn 2010-2015.

\section{Phương pháp và nội dung nghiên cứu}

\subsection{Phương pháp nghiên cúu}

Để tìm hiểu về những kết quả đã đạt được trong công tác phổ cập giáo dục mầm non cho trẻ 5 tuổi ở tỉnh Thái Nguyên thể hiện trên các lĩnh vực: Cơ sở giáo dục mầm non, đội ngũ giáo viên và người học. Bài viết sử dụng hai phương pháp nghiên cứu chính là định lượng và định tính. Phương pháp định lượng nhằm phân tích những chính sách, giải pháp, kết quả đã đạt được sau khi thực hiện các chính sách phổ cập giáo dục mầm non. Nguồn số liệu cho phân 
tích định lượng chủ yếu lấy từ các báo cáo tổng kết của Sở Giáo dục và Đào tạo tỉnh Thái Nguyên về công tác phổ cập giáo dục mầm non. Phương pháp định tính được sử dụng để xác định rõ những khó khăn khi thực hiện phổ cập giáo dục mầm non cho trẻ 5 tuổi ở tỉnh Thái Nguyên. Từ đó, chúng tôi đưa ra các khuyến nghị nhằm củng cố vững chắc kết quả phổ cập giáo dục cấp học mầm non.

\subsection{Nội dung nghiên cúu}

2.2.1. Co sở lý luận của phổ cập giáo duc mầm non cho trẻ 5 tuổi

Ngày 09/02/2010, Thủ tướng Chính phủ ban hành Quyết định số 239/QĐ-TTg phê duyệt Đề án Phổ cập giáo dục mầm non cho trẻ em 5 tuổi giai đoạn 2010 - 2015. Mục tiêu của Đề án nhằm bảo đảm trẻ 5 tuổi ở mọi vùng miền được đến lớp học 2 buổi/ngày để chuẩn bị tốt về mọi mặt, đặc biệt là trẻ em DTTS được học tiếng Việt và tâm lý sẵn sàng đi học, bảo đảm chất lượng vào lớp 1 .

Phổ cập giáo dục mầm non cho trẻ em 5 tuổi được hiểu là mọi trẻ em 5 tuổi đều được theo học ở hệ thống cơ sở giáo dục mầm non và hoàn thành chương trình giáo dục mầm non cho trẻ 5 tuổi. Tuy nhiên, trong bối cảnh người dân sống ở vùng sâu, vùng $x a$, vùng dân tộc thiểu số còn nhiều khó khăn, khả năng tiếp cận cơ sở hạ tầng, các dịch vụ công và điều kiện giáo dục còn hạn chế, do vậy thực hiện phổ cập giáo dục mầm non gắn liền với việc vận động người dân đưa trẻ đến trường học, đầu tư xây dựng cơ sở vật chất và khắc phục tình trạng thiếu giáo viên, đảm bảo chế độ chính sách cho giáo viên.

Để thực hiện phổ cập giáo dục mầm non cho trẻ em 5 tuổi, Nhà nước huy động cả hệ thống chính trị vào cuộc, giành ngân sách ưu tiên hỗ trợ cơ sở vật chất, đầu tư trang thiết bị dạy học, đồ dùng, đồ chơi, đào tạo đội ngũ giáo viên, bố trí đủ giáo viên cho các lớp mầm non 5 tuổi ở miền núi, vùng sâu, vùng $x a$, các vùng có điều kiện kinh tế - xã hội đặc biệt khó khăn, biên giới, hải đảo. Nhà nước hỗ trợ tiền ăn trưa cho trẻ em mẫu giáo 3- 5 tuổi, miễn giảm kinh phí học tập cho trẻ em học mẫu giáo thuộc hộ nghèo là người dân tộc thiểu số ở vùng có điều kiện kinh tế - xã hội đặc biệt khó khăn, thực hiện cấp bù kinh phí trực tiếp cho các cơ sở giáo dục mầm non (Chính phủ, 2013, khoản 1 điều 4, khoản 2 điều 7).

2.2.2. Thực trạng phổ cập giáo dục mầm non cho trẻ 5 tuổi ở tỉnh Thái Nguyên

\subsubsection{Công tác triển khai, thục hiện}

Là tỉnh nằm ở khu vực trung $\mathrm{du}$ và miền núi phía Bắc, địa hình phức tạp, Thái Nguyên có 125 xã vùng cao, miền núi và 36 xã thuộc diện kinh tế - xã hội đặc biệt khó khăn theo quyết định của Chính phủ. Tại các xã này, cơ sở hạ tầng, các dịch vụ công và điều kiện giáo dục của đồng bào còn hạn chế, tỷ lệ hộ nghèo và cận nghèo còn cao, nhiều xã không có trường mầm non, nhiều trẻ em không được đi học mẫu giáo khiến trẻ gặp nhiều khó khăn khi đi học lớp 1, hạn chế khả năng tiếp thu kiến thức, học tập và hòa nhập.

Để bảo đảm mọi trẻ em 5 tuổi đều được đến trường, tỉnh Thái Nguyên xác định phổ cập giáo dục mầm non cho trẻ 5 tuổi là trách nhiệm của cả hệ thống chính trị và triển khai đồng bộ nhiều giải pháp, tăng cường mọi nguồn lực đầu tư cho giáo dục mầm non. Tỉnh thành lập và kiện toàn Ban Chỉ đạo phổ cập giáo dục mầm non cho trẻ em 5 tuổi. Các thành viên trong Ban Chỉ đạo tăng cường phối hợp kiểm tra giám sát, hỗ trợ các hoạt động trong quá trình triển khai thực hiện theo đúng kế hoạch và lộ trình. Nhằm thực hiện thống nhất công tác phổ cập giáo dục mầm non cho trẻ 5 tuổi, có hiệu quả, Tỉnh đã ban hành nhiều văn bản chỉ đạo trong giai đoạn 2010- 2020 (xem biểu đồ 1).

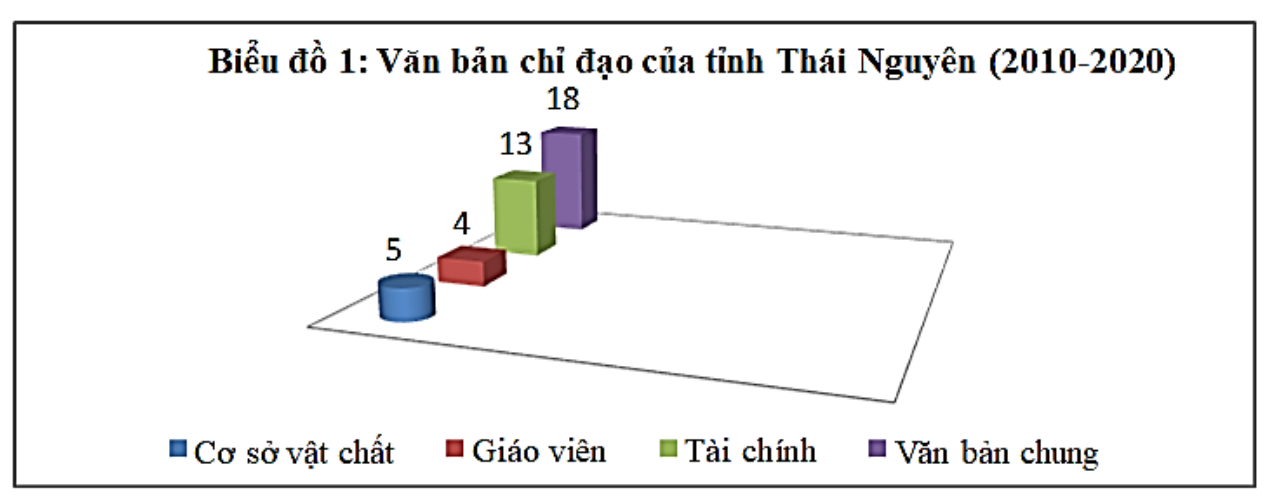

Nguồn: Các tác giả tổng hợp 
Ngoài ra, Sở Giáo dục và Đào tạo tỉnh Thái Nguyên với vai trò là cơ quan thường trực Ban Chỉ đạo Phổ cập giáo dục (PCGD) đã ban hành trên 50 văn bản để chỉ đạo Phòng Giáo dục và đào tạo các huyện, thành phố, thị xã, tham mưu với uỷ ban nhân dân các huyện đưa mục tiêu của công tác PCGD vào nội dung, chương trình hành động của các cấp chính quyền.

Các cấp, các ngành, đặc biệt là Sở Giáo dục và Đào tạo phối hợp với đài Phát thanh và Truyền hình Tỉnh, báo Thái Nguyên tuyên truyền, phổ biến về phổ cập giáo dục mầm non cho trẻ 5 tuổi. Các cơ sở giáo dục mầm non đều có góc tuyên truyền về công tác PCGD với nội dung thiết thực, phong phú, đồng thời thực hiện lồng ghép nội dung tuyên truyền thông qua các buổi họp phụ huynh, ngày hội toàn dân đưa trẻ đến trường, hội thi, hội nghị, hội thảo chuyên đề, họp phụ huynh, họp thôn, bản, khu phố,... góp phần tạo sự chuyển biến tích cực trong nhận thức, sự đồng thuận, cộng đồng trách nhiệm trong phối hợp tổ chức thực hiện các mục tiêu, nhiệm vụ về công tác PCGD cho trẻ em 5 tuổi.

Nhằm nâng tỷ lệ huy động trẻ đến trường, tỉnh Thái Nguyên rà soát số trẻ trong độ tuổi để có kế hoạch mở các điểm trường mầm non, lớp mẫu giáo ở những nơi giao thông không thuận tiện; đưa chỉ tiêu phát triển mạng lưới trường, lớp, huy động trẻ đến trường vào kế hoạch phát triển kinh tế - xã hội theo từng năm; lồng ghép các nguồn kinh phí từ chương trình 135 , xây dựng nông thôn mới, chương trình vệ sinh, nước sạch...; đẩy mạnh xã hội hóa giáo dục để xây dựng trường, lớp học, xóa phòng học tạm, xây dựng bổ sung nhiều công trình phụ trợ; trang bị đồ dùng, thiết bị, đồ chơi cho các trường, nhóm, lớp mầm non; thực hiện đúng chế độ chính sách, đảm bảo đời sống của đội ngũ giáo viên, nhân viên, chế độ cho trẻ theo quy định của Trung ương và địa phương. Tỉnh cũng ban hành chính sách chuyển trường mầm non bán công sang công lập để đảm bảo quyền tự chủ, tự chịu trách nhiệm về thực hiện nhiệm vụ, tổ chức bộ máy, biên chế và tài chính đối với đơn vị sự nghiệp công lập theo nghị định 43/2006/NĐ-CP của Chính phủ và các quy định hiện hành của nhà nước.

Đối với giáo viên, nhận viên trong diện hợp đồng làm nhiệm vụ nấu ăn trong các trường mầm non công lập, tỉnh Thái Nguyên có chế độ hỗ trợ kinh phí, đồng thời Tỉnh thực hiện cấp phát đồ dùng, đồ chơi trong lớp và đồ chơi ngoài trời, tài tiệu cho giáo viên, tổ chức các lớp tập huấn cho giáo viên làm việc trong các cơ sở giáo dục mầm non ngoài công lập. Từ năm 2018, tỉnh Thái Nguyên thực hiện chính sách hỗ trợ ăn trưa đối với trẻ em mẫu giáo và chính sách đối với giáo viên mầm non, chi trả hỗ trợ đối với giáo viên được hưởng chế độ dạy lớp ghép, hỗ trợ tăng cường tiếng Việt và hỗ trợ giáo viên hợp đồng trong phòng chống dịch Covid - 19. Tỉnh cũng chỉ đạo ưu tiên bố trí, sắp xếp giáo viên đạt trên chuẩn về trình độ đào tạo, có chuyên môn vững vàng, nhiều kinh nghiệm trong quá trình chăm sóc giáo dục trẻ được dạy lớp 5 tuổi.

Với sự chung tay của toàn hệ thống chính trị, các tổ chức, cá nhân, tỉnh Thái Nguyên đã huy động được mọi nguồn lực đầu tư phát triển giáo dục mầm non công lập và ngoài công lập, đáp ứng nhu cầu đưa trẻ đến trường của nhân dân; giảm tình trạng quá tải số trẻ/lớp trong các cơ sở giáo dục mầm non công lập, góp phần nâng cao chất lượng chăm sóc, giáo dục trẻ, đảm bảo các điều kiện thực hiện PCGD, tạo nên diện mạo mới đối với giáo dục mầm non.

\subsubsection{Kết quả đạt được}

\section{- Cơ sở vật chất và đội ngũ giáo viên}

Thực hiện phổ cập giáo dục cho trẻ mầm non phụ thuộc vào chất lượng đội ngũ giáo viên và điều kiện cơ sở vật chất trường, lớp, trang thiết bị đồ dùng, đồ chơi đảm bảo cho công tác chăm sóc, giáo dục trẻ.

Tỉnh Thái Nguyên có nhiều xã thuộc diện kinh tế - xã hội đặc biệt khó khăn, mạng lưới trường lớp mầm non thiếu, manh mún, cơ sở vật chất nghèo nàn, nhiều điểm trường mầm non phải mượn nhà văn hóa của thôn xã, nhà dân làm lớp học, nhiều nơi phòng dựng tạm vách tre, mái lá, không có nước sinh hoạt. Để mở rộng mạng lưới trường, lớp mầm non, Tỉnh đã chỉ đạo các địa phương huy động xã hội hóa, dành nguồn kinh phí đầu tư mở rộng, xây dựng cơ sở vật chất cho các trường mầm non. Chính vì vậy, số trường mầm non trong và ngoài công lập, số điểm trường tăng lên rõ rệt (bảng 1). 
N.T.Q.Loan et al/ No.23_Oct 2021|p.15-22

Bảng 1: Thống kê số trường/điểm trường mầm non của tỉnh Thái Nguyên (2010-2020)

\begin{tabular}{|l|c|c|}
\hline \multicolumn{1}{|c|}{ Số trường/điểm trường } & Năm học 2010-2011 & Năm học 2019-2020 \\
\hline Trường mầm non công lập & 202 & 216 \\
\hline Trường mầm non tư thục & 5 & 26 \\
\hline Số điểm trường mầm non & 263 & 493 \\
\hline
\end{tabular}

Nguồn: Sở Giáo dục và Đào tạo tỉnh Thái Nguyên, 2020, tr.4.

Nếu như năm học 2010- 2011, tổng số phòng học mầm non là 1.967 phòng với 389 phòng kiên cố (chiếm tỷ lệ 19,77\%) thì đến năm học 2019-2020 đã tăng lên 3.142 phòng, trong đó, có 1.902 phòng học kiên cố (Sở Giáo dục và Đào tạo, 2020, tr.4). Nhiều phòng học tạm, tranh tre, nứa, lá ở vùng sâu vùng xa đã được xây dựng khang trang, có khu bếp ăn mới, nước giếng khoan, công trình vệ sinh, đảm bảo đạt 01 phòng/lớp mẫu giáo 5 tuổi, diện tích $1,5 \mathrm{~m}^{2} /$ trẻ trở lên. Từ năm $2014,100 \%$ phòng học lớp mẫu giáo 5 tuổi được trang bị đủ đồ dùng và trang thiết bị tối thiểu (biểu đồ 2 ) đảm bảo tiêu chuẩn, đáp ứng được cơ bản nhu cầu, chất lượng chăm sóc giáo dục trẻ mầm non.

\section{Biểu đồ 2: Số lớp mẫu giáo 5 tuổi và lớp đủ đồ dùng, trang thiết bị tối thiểu (2010-2019)}

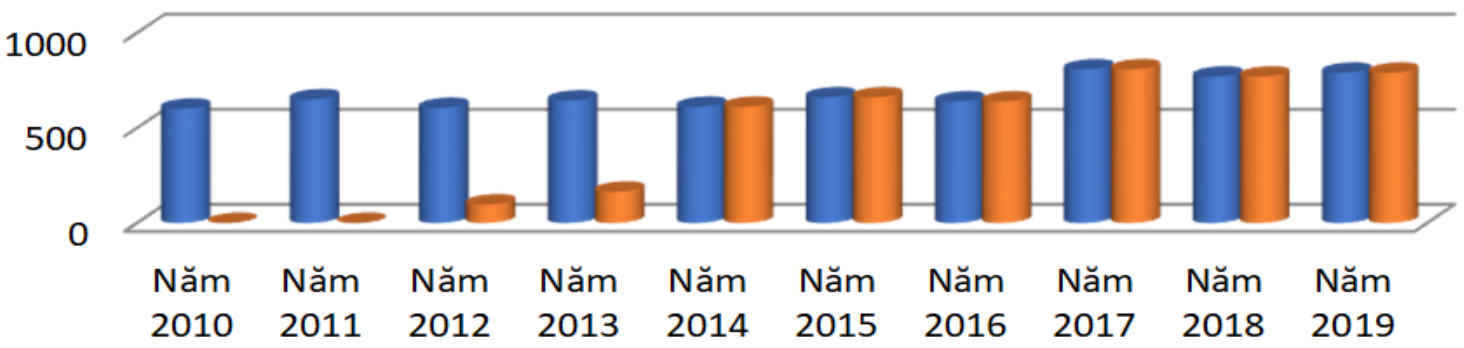

Số lớp mẫu giáo 5 tuổi ㅁố lớp mẫu giáo 5 tuổi đủ đồ dùng, trang thiết bị tối thiểu

Nguồn: Các tác giả tổng hợp

Tuy nhiên, do một số địa phương địa bàn rộng, dân cư thưa thớt, nên khó khăn cho việc sáp nhập các điểm trường. Các điểm trường lẻ có vị trí cách xa điểm trường chính, còn lớp học ghép các độ tuổi, do đó công tác tổ chức hoạt động chăm sóc, giáo dục trẻ rất khó khăn. Vẫn còn những điểm trường phải học nhờ trường phổ thông, nhà văn hóa, một số phòng học, phòng chức năng chưa đảm bảo đủ diện tích theo tiêu chuẩn quy định. Hệ thống trường lớp, phòng học, trang thiết bị đồ dùng, đồ chơi mặc dù đã được đầu tư nhưng còn thiếu.

Cùng với việc đầu tư xây dựng trường, lớp học, nâng cấp cơ sở vật chất, tạo điều kiện thuận lợi cho giáo viên tổ chức các hoạt động chăm sóc, giáo dục giúp trẻ phát triển toàn diện, tỉnh Thái Nguyên chú trọng đến công tác bồi dưỡng nâng cao năng lực, nghiệp vụ cho đội ngũ giáo viên.

Trong giai đoạn 2011-2020, Tỉnh đã tổ chức trên 20 lớp tập huấn về công tác phổ cập với trên 4.140 lượt cán bộ quản lý, giáo viên mầm non tham gia; cấp huyện tổ chức được 285 cuộc với 8.485 lượt người; cấp xã tổ chức được 1.926 cuộc với 29.388 lượt người tham gia (Ban Chỉ đạo Phổ cập Giáo dục, xoá mù chữ, 2021, tr.5).

Đội ngũ giáo viên mầm non của Tỉnh ngày càng phát triển theo hướng chuẩn hóa, tăng về số lượng, đảm bảo trình độ chuyên môn nghiệp vụ, đáp ứng nhiệm vụ của người giáo viên mầm non vừa chăm lo, dạy dỗ cho trẻ em vừa là những người đặt nền móng đầu tiên cho bước đường trưởng thành của trẻ, uốn nắn, tập cho trẻ những thói quen, kỹ năng sống, đem lại cho trẻ cảm giác tin tưởng, được quan tâm, bảo vệ khi đến trường.

Trong giai đoạn từ 2010-2020, Tỉnh đã tuyển trên 1.600 giáo viên hợp động vào biên chế và trên 2.000 nhân viên nấu ăn làm việc tại các cơ sở giáo dục mầm non. Để đảm bảo thực hiện PCGD mầm non cho trẻ 5 tuổi, Tỉnh chỉ đạo sắp xếp những giáo viên dạy lớp mẫu giáo 5 tuổi là giáo viên đạt chuẩn/trên chuẩn về trình độ đào tạo, có chuyên 
môn vững vàng, nhiều kinh nghiệm trong quá trình chăm sóc giáo dục trẻ, được đánh giá xếp loại khá trở lên về chuẩn nghề nghiệp giáo viên mầm non. Từ năm 2012, 100\% giáo viên dạy lớp mẫu giáo 5 tuổi đạt trình độ đào tạo chuẩn và từ năm 2015 , trên $90 \%$ trở lên giáo viên đạt trình độ đào tạo trên chuẩn (biểu đồ 3).

Biểu đồ 3: Tổng hợp chất lượng giáo viên dạy lớp mẫu giáo 5 tuổi (2010-2019)

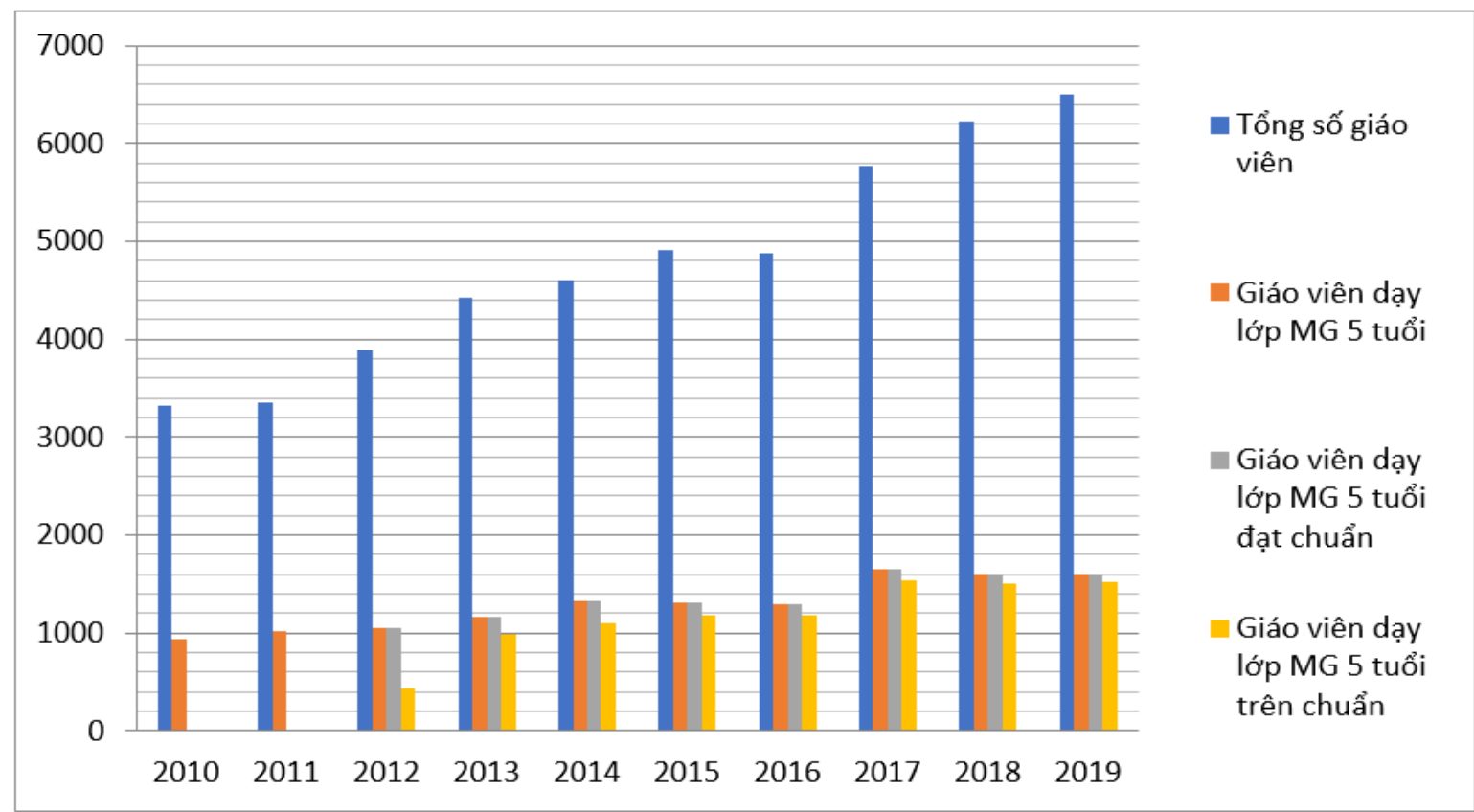

Tỉnh Thái Nguyên đảm bảo việc hỗ trợ kinh phí thực hiện chế độ chính sách đối với lao động hợp đồng làm giáo viên trong các trường mầm non và nhân viên làm nhiệm vụ nấu ăn trong các trường mầm non công lập; thực hiện chi trả hỗ trợ đối với giáo viên được hưởng chế độ dạy lớp ghép, tăng cường tiếng Việt và giáo viên hợp đồng trong phòng chống dịch Covid - 19; cấp phát tài tiệu, tổ chức các lớp tập huấn cho giáo viên mầm non ngoài công lập. Do đó Tỉnh đã huy động được sự tham gia của các tổ chức, cá nhân đầu tư phát triển loại hình giáo dục mầm non ngoài công lập, ổn định đội ngũ giáo viên ngoài công lập; đáp ứng nhu cầu đưa trẻ đến trường của nhân dân; giảm tình trạng quá tải số trẻ/lớp trong các cơ sở giáo dục mầm non công lập, nâng cao chất lượng chăm sóc, giáo dục trẻ, đảm bảo các điều kiện thực hiện PCGD mầm non trẻ em 5 tuổi.

Về cơ bản, số lượng và chất lượng đội ngũ giáo viên mầm non của Tỉnh đã được nâng lên, song vẫn còn thiếu giáo viên. Mức tiền công của hợp đồng khoán việc trong các trường còn thấp không thu hút được giáo sinh mới ra trường đến làm việc nhất là
Nguồn: Các tác giả tổng hợp đối với các trường ở vùng sâu, vùng $\mathrm{xa}$, điều kiện giao thông không thuận lợi. Nhân viên nấu ăn của một số trường mầm non chưa đảm bảo theo quy định. Do khó khăn về nguồn kinh phí nên Tỉnh chưa có chính sách hỗ trợ cán bộ, giáo viên, nhân viên thực hiện công tác phổ cập giáo dục mầm non cho trẻ em 5 tuổi.

\section{- Đối với nguời học}

Nhằm tạo điều kiện thuận lợi cho trẻ ra lớp ở những điểm dân cư không tập trung, ngoài việc mở các điểm trường mầm non, lớp mẫu giáo, tỉnh Thái Nguyên chỉ đạo các địa phương chủ động rà soát số trẻ trong độ tuổi, cử giáo viên phối hợp với các đoàn thể đến từng thôn, xóm vận động, tuyên truyền cho phụ huynh hiểu tầm quan trọng, ý nghĩa, mục tiêu, nhiệm vụ của phổ cập giáo dục mầm non trong chăm sóc, giáo dục trẻ, nhằm tạo sự đồng thuận, tham gia tích cực của cộng đồng, phụ huynh trong công tác PCGD mầm non cho trẻ 5 tuổi, tạo điều kiện tốt nhất để trẻ em được sinh hoạt, học tập, vui chơi trong môi trường giáo dục an toàn, lành mạnh, thân thiện. Nhờ sự chung tay, góp sức của cộng đồng, số trẻ 5 tuổi ra lớp trong các năm đều tăng (biểu đồ 4) 


\section{Biểu 4: Số trẻ 5 tuổi được PCGD mầm non (2010-2020)}

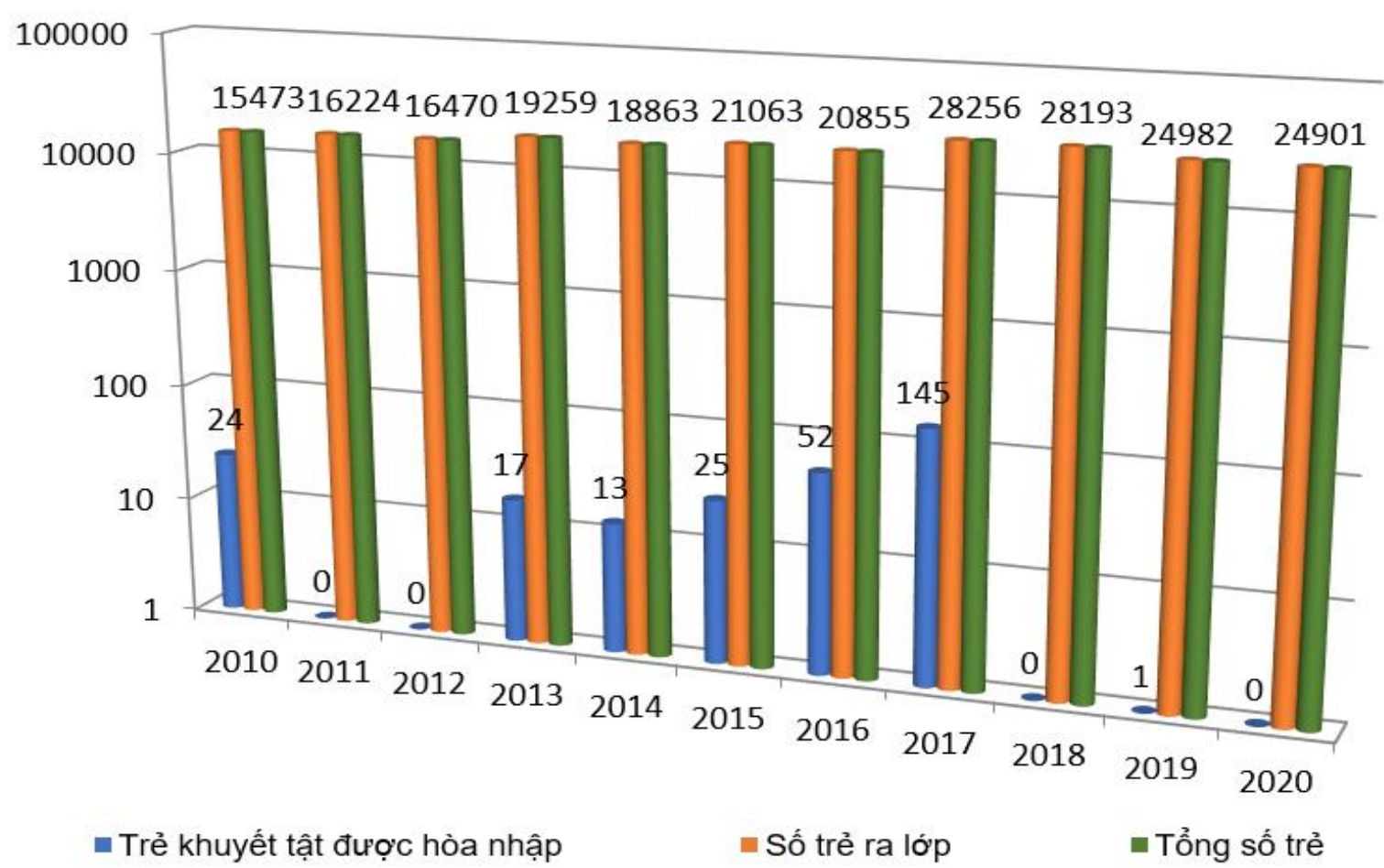

Nguồn: Các tác giả tổng hơp

Ngoài đảm bảo về số lượng, chất lượng giáo dục và chăm sóc trẻ luôn được các trường chú trọng. Trong quá trình xây dựng kế hoạch giáo dục, 100\% lớp mẫu giáo 5 tuổi tham khảo thực hiện Bộ chuẩn phát triển trẻ em 5 tuổi. Trẻ được đánh giá toàn diện theo các lĩnh vực phát triển thể chất, nhận thức, ngôn ngữ, tình cảm kỹ năng xã hội và thẩm mỹ. Số trẻ khuyết tật ra lớp học hòa nhập có sự tiến bộ rõ rệt. Thực hiện Kế hoạch số 45/KH-UBND ngày 23/03/2017 của Uỷ ban nhân dân tỉnh Thái Nguyên về triển khai thực hiện Đề án "Tăng cường tiếng Việt cho trẻ em mầm non, học sinh tiểu học vùng dân tộc thiểu số giai đoạn 2016-2020, định hướng đến 2025 ", tại các trường/điểm trường có kế hoạch xây dựng môi trường tăng cường nghe nói tiếng Việt cho trẻ, huy động sự tham gia của cha mẹ trẻ, do đó, $100 \%$ số trẻ 5 tuổi dân tộc ra lớp được chuẩn bị tiếng Việt trước khi vào học lớp 1.

Để nâng cao chất lượng chăm sóc trẻ, các trường luôn đảm bảo vệ sinh an toàn thực phẩm và làm tốt công tác nuôi dưỡng, chăm sóc, bảo vệ sức khỏe cho trẻ. Hằng năm, nhân viên y tế các trường thực hiện khám sức khỏe định kỳ cho các bé 2 lần/năm và theo dõi sức khỏe bằng biểu đồ tăng trưởng. So với năm học 2010-2011, số trẻ 5 tuổi được học 2 buổi/ngày và được ăn bán trú tăng 8.677 trẻ (Sở Giáo dục và Đào tạo tỉnh Thái Nguyên, tr.9). Với sự cố gắng, nỗ lực của toàn hệ thống chính trị, sự chung tay của cộng đồng, năm 2012, Thái Nguyên đã có 97/181 xã, phường, thị trấn đạt chuẩn PCGD mầm non cho trẻ em 5 tuổi. Năm 2013 có 164/181xã, phường, thị trấn đạt chuẩn PCGD mầm non cho trẻ em 5 tuổi và đến năm 2016, 180/180 xã, phường, thị trấn ${ }^{2}$ đạt chuẩn PCGD mầm non cho trẻ em 5 tuổi (Sở Giáo dục và Đào tạo tỉnh Thái Nguyên, tr.10).

\section{Kết luận và các biện pháp đề xuất}

Trong suốt quá trình lãnh đạo, Đảng, Nhà nước Việt Nam luôn coi trọng vai trò của giáo dục và đào tạo, coi phát triển giáo dục và đào tạo là một trong những nhiệm vụ quan trọng, là quốc sách hàng đầu. Chính vì vậy, Đảng và Nhà nước đã có nhiều chủ trương, chính sách, đề án phát triển giáo dục, trong đó có đề án PCGD mầm non cho trẻ em 5 tuổi.

Sau 10 năm thực hiện PCGD mầm non cho trẻ em 5 tuổi (2010-2020), tỉnh Thái Nguyên đã đạt các mục tiêu, nhiệm vụ về phát triển giáo dục mầm non nói chung và công tác PCGD mầm non cho trẻ em 5 tuổi nói riêng. Hệ thống cơ sở vật chất trong các cơ sở giáo dục mầm non; quy mô trường, nhóm,

\footnotetext{
${ }^{2}$ Năm 2016 có sự sáp nhập giữa các xã, phường, thị trấn.
} 
lớp, tỷ lệ huy động trẻ em trong 10 năm qua đã tăng, đảm bảo đáp ứng các yêu cầu tiêu chuẩn, nhu cầu phát triển và chất lượng chăm sóc giáo dục trẻ mầm non. Những thành tựu về PCGD mầm non cho trẻ 5 tuổi của các cơ sở giáo dục mầm non ở tỉnh Thái Nguyên đã khẳng định hiệu quả của việc triển khai thực hiện các Đề án, Chương trình, các kế hoạch của Tỉnh giai đoạn 2010-2020.

Bên cạnh những thành tựu đạt được, công tác PCGD mầm non cho trẻ em 5 tuổi vẫn còn những khó khăn, hạn chế. Do vậy để thực hiện tốt công tác PCGD mầm non cho trẻ 5 tuổi và củng cố vững chắc kết quả phổ cập giáo dục cấp học mầm non theo chúng tôi cần:

- Tiếp tục thực hiện tốt công tác tuyên truyền, huy động nguồn kinh phí đóng góp từ các tổ chức xã hội, các đoàn thể của địa phương để tăng cường cơ sở vật chất, xây dựng cảnh quan môi trường giáo dục sạch, đẹp, thu hút học sinh đến trường; tạo điều kiện cho các tổ chức, cá nhân đầu tư xây dựng trường, lớp mầm non ngoài công lập. Các cấp, các ngành tiếp tục phối hợp, truyên truyền, huy động các nguồn hỗ trợ, đóng góp từ các tổ chức, cá nhân, các nhà hảo tâm, doanh nghiệp để xây dựng cơ sở vật chất cho GDMN; ưu tiên nguồn kinh phí của tỉnh để xây dựng đủ phòng phòng chức năng, phòng học, xóa lớp học nhờ; trang bị bổ sung đồ dùng, thiết bị cho các trường, nhóm, lớp mầm non; quy hoạch phát triển mạng lưới trường, lớp, các điểm trường vùng cao, vùng sâu, vùng xa, địa bàn thành phố, thị xã, thị trấn đông dân cư để đáp ứng nhu cầu cho con đến trường của người dân, khắc phục tình trạng quá tải số trẻ trên lớp.

- Tiếp tục mở các lớp đào tạo nâng chuẩn trình độ, bồi dưỡng nghiệp vụ, tạo điều kiện thời gian và hỗ trợ kinh phí cho các giáo viên theo học để nâng cao chất chất lượng tay nghề. Trong điều kiện số trẻ đến trường mầm non tăng nhanh và số lượng giáo viên biên chế được giao còn thiếu so với quy định, cần có chính sách đào tạo, hỗ trợ kinh phí cải thiện mức sống, thu nhập cho giáo viên, có kinh phí hỗ trợ chế độ làm thêm giờ, chế độ trực trưa đối với giáo viên mầm non để họ yên tâm làm việc và cống hiến cho sự nghiệp giáo dục mầm non. Với các cơ sở giáo dục mầm non cần bổ sung định mức nhân viên nấu ăn trong khung vị trí việc làm để thực hiện tốt nội dung chăm sóc, nuôi dưỡng trẻ em.

\section{REFERENCES}

[1] Steering Committee for Universal Education and Literacy Elimination. (2021). Report on implementation results of Directive No. 10-CT/TW, dated December 5, 2016 of the Politburo (term XI). On universalizing preschool education for 5-yearold children, consolidating educational universalization results primary and lower secondary schools, strengthen the stream of students after lower secondary school, and eliminate adult illiteracy. BC-SGDDT, June 2021.

[2] Government. (2011). Decree amending and supplementing a number of articles of Decree No. 75/2006/ND-CP dated August 2, 2006 of the Government detailing and guiding the implementation of a number of articles of the Education Law. No. 31/2011/ND-CP dated 11/6/2011. https://thuvienphapluat.vn/vanban/Giao-duc/Nghi-dinh-31-2011-ND-CP.

[3] Government. (2013). Decree on tuition fee exemption and reduction, support for study expenses and mechanism for collection and use of tuition fees for educational institutions under the national education system from the 2010-2011 school year to the 2014-2015 school year. Decree No. 74/2013/ND-CP dated 15/07/2013. https://huvienphapluat.vn/van-ban/Giao-duc/Nghidinh-74-2013

[4] National Assembly. (2009). Law amending and supplementing a number of articles of the Law on Education. No. 44/2009/QH12. https://thuvienphapluat.vn/van-ban/Giao-duc/LuatGiao-duc-sua-doi-nam-2009

[5] Department of Education and Training of Thai Nguyen Province. (2020). Report on the results of 10 years of implementation of universal preschool education for 5-year-old children, period 2010-2020. Report No. 1780/SGDĐT-GDMN, August 25, 2020.

[6] Prime Minister. (2010). Decision approving the Project on Universalizing Early Childhood Education for five-year-old children in the period 2010 - 2015. https://thuvienphapluat.vn/vanban/Giao-duc/quyet-dinh-239-qd-ttg 